\title{
Mentoring African American Expatriates: Providing The Bridge To Success Abroad
}

Daria C. Crawley, Ph.D., Robert Morris University, USA

Charlotte Broaden, Ph.D., Southern New Hampshire University, USA

Darlene Y. Motley, Ph.D., Robert Morris University, USA

\begin{abstract}
Employment predictions continue to forecast increasing racial diversity in the American workforce as firms face global competition and strive to grasp the challenges of a global business landscape. As American multinational corporations use expatriate assignments; supplemented by flexipatriates and inpatriates to meet customer preferences in the global marketplace, growing racial diversity may generate more expatriates of color. Global human resource management research has focused on issues such as adjustment and cross-cultural development and recently mentoring as critical factors for expatriate success. A growing body of mentoring research details the career experiences of employees with diverse backgrounds, yet few studies center on the experiences of the African American expatriate. This article aims to examine African Americans mentoring opportunities in a global environment, with a focus on understanding the role mentoring plays for this particular population group. This work is intended to contribute to the increasing literature on global mentoring and will help to influence the thinking of multinational corporations' response to the increasing diversity of their global workforce.
\end{abstract}

Keywords: Diversity, Mentoring, Expatriates

\section{INTRODUCTION}

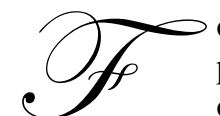

or years, researchers have analyzed the changing demographics of the American workforce. Current projections forecast an increase in the number of working women, people of color, immigrants, and older workers in the labor force. The Hudson Institute's breakthrough study, Workforce 2000 reported that American businesses throughout the remainder of the century would face a dramatically different labor market than they had been accustomed to in decades past. While many companies are increasingly attentive to workforce diversity in their American operations, global demographic changes combined with international competition and the mobility of the global workforce (Iles, 1995; Humphries and Grice, 1995; Konrad, 2003; Sippola and Smale, 2007) make workforce diversity a critical issue for multinational corporations (MNCs). In a survey examining global diversity issues, results indicated that $100 \%$ of the organizations surveyed indicated that global diversity was either an important or very important issue (Dunavant and Heiss, 2005).

Although MNCs value global diversity, limited research exists on their global diversity initiatives. Wentling and Palma-Rivas (2000) provided a groundbreaking survey of domestic and international diversity efforts by MNCs, which found numerous domestic initiatives and, comparatively, only a few international initiatives, (116 versus 7). The survey noted that while the firms international diversity efforts were often at the preliminary planning or early implementation stages, half of the firms responding, "planned to develop their current international diversity initiatives more aggressively in the future" (Wentling \& Palma-Rivas 2000: 53). Although many corporations' global diversity efforts are in developmental stages, we agree with Florkowski (1996), that, for all of its uncertainties, global diversity management holds "the key competitive advantage for companies that seek to enter and succeed in international markets".

The growing labor force participation rates of America's racial minority populations (Toosi, 2005), combined with multinationals' growing attention to global diversity and the desire to develop global talent that can understand their international customers' preferences, may generate increasing numbers of 'people of color' pursuing 
expatriate careers. Although, data on the number of racial minority expatriates is limited, a survey of expatriate managers reported the median as $10 \%$ among companies who tracked minority racial expatriate representation (ORC Worldwide, 2002)). Little, if any, research exists that examines racial minorities' expatriate experiences and to the extent that MNCs believe that success abroad depends on ensuring diversity amongst their expatriate managers, it is critical that MNCs pay attention to this segment of their expatriate workforce (ORC Worldwide, 2002).

Corporations often use mentoring, the process through which employees learn corporate culture and techniques on navigating the business environment, to develop employees. From a traditional mentoring perspective a mentor, a more senior experienced executive, provides guidance, advice and uses his or her influence and power to advance the career of a protégé, junior, less experienced employee (Kram, 1985). While contemporary views of mentoring draw attention to peer and reverse mentoring, a common component of each of these variations is the development relationship that is embedded in a career context (Ragins and Kram, 2007). Research indicates the positive impact of mentor support on a wide range of organizational outcomes including promotions (Dreher and Ash, 1990; Whitely, W and Coetsier, 1993), compensation (Whitely, Dougherty and Dreher, 1991; Dreher and Cox, 1996; Chao, 1997; Dreher and Cargio, 1998); and career and job satisfaction (Fagenson, 1989; Bahniuk, Dobos and Hill, 1990; Koberg, Boss, Chappell and Ringer, 1994). A vital factor in achieving these outcomes is communication between the mentor and protégé. Communication, the primary medium by which mentors and protégés engage in the critical information exchange, serves as the foundation of their relationship. Research suggests that the level of open communication establishes a safe haven whereby mentors and protégés share competencies and strategies (Ensher and Murphy, 1997, Lankau and Scandura, 2002; Mullen, 1994, Olian et. al. 1993 and Ostroff and Kozlowski, 1993).

For expatriates this information exchange is essential as they navigate and strive to meet performance expectations in a different cultural context. An emergent body of research suggests that mentoring may assist expatriates who often face ambiguity, uncertainty, and pressures stemming from challenges of international assignments (Feldman and Thomas, 1992; Harvey and Wiese, 1998; Mezias and Scandura, 2005). Findings also suggest that mentors help expatriates reduce stress (Feldman and Thomas, 1992; Vermond, 2001); manage their experiences (Feldman and Thomas, 1992); adjust to foreign cultures (Harvey and Wiese, 1998); reduce uncertainty about new assignments which helps them learn and adjust to their work roles quickly (Ostroff and Kozlowski, 1999); look out for the expatriates' interest in the home office while they are away (Vermond, 2001) and help returning expatriates adjust to the home office (Downes, Thomas and Singley, 2002; Vermond, 2001; Swaak, 1997).

Despite the growing interest in American employees' mentoring relationships domestically and internationally, Blake-Beard, Murrell and Thomas (2007), in their discussion of race in the context of mentoring, highlight the paucity of research in this area. In Davison and Punnett's (1995) study examining issues of gender and race in the context of international assignment decisions, they note that gender and race receive relatively little attention despite the impact of these variables on the actual expatriate assignment decision. Acknowledgement of the positive organizational benefits of mentoring and increasing attention by MNCs to global diversity, coupled with the rise in international assignments, merits research attention to the mentoring experiences of diverse expatriates. We agree with Blake-Beard, Murrell and Thomas (2007) who appeal for "a greater inclusion of race within the context of mentoring research" and Mezias and Scandura (2005) who assert that the demographic profile of the mentor and protégé may affect international adjustment and mentoring outcomes and call for "theory and research examining the role of diversity in the development of mentoring in the international context". Expansion of the international marketplace in concert with changing global demographics and growing appreciation of the economic benefits derived from diversity (Cox and Blake, 1991) warrant consideration of African American expatriates' mentoring relationships.

The purpose of this paper is to address the gap in the literature highlighting essential elements of the mentoring experiences of African American expatriates. Although researchers often study individuals considered racial minorities in America; (Blacks, Asians, Native Americans); as one large group, we recognize the historical differences between these groups and instead of clouding the waters, choose to focus solely African Americans. To accomplish this, a brief review of the mentoring literature as it relates to expatriates and racially diverse employees is provided. Next, attention is shifted to the relational demography literature as a framework to highlight the role of demographic factors in relationships between African American expatriates and their mentors. This is followed by a discussion on an expatriate's adjustment to describe racial/ethnic minority expatriates' mentoring experiences. The paper concludes with a discussion on implications for theory and practice. 


\section{MENTORING}

Kram's (1985) seminal work investigating the developmental relationships of 18 senior and junior managers in a utility company developed a dichotomy between mentoring functions. She characterizes the career functions, behaviors that enhance advancement in the organization as exposure and visibility, coaching, sponsorship, protection, and challenging assignments (Kram, 1985). Alternatively, psychosocial functions enhance protégés' sense of competence, confidence, effectiveness, and esteem and include role modeling, counseling, acceptance and confirmation, and friendship (Kram, 1985). Subsequent mentoring research indicates the positive impact of mentor support on promotions, compensation, career, and job satisfaction (Allen, Eby, Poteet, Lentz \& Lima, 2004; Dreher and Ash, 1990; Dreher and Cox, 1996; Fagenson, 1989; Koberg, Boss, Chappell and Ringer, 1994; Whitely, and Coetsier, 1993; Whitely, Dougherty and Dreher, 1991).

Research examining the complexity of the expatriate experience suggests that a mentor aids employees during each phase of the international work assignment from pre-departure, to expatriation, to repatriation (Harvey, Buckley, Novicevic, and Wiese, 1999a). Kamoche's (2000) exploration of culture and management training/development programs focused on creating international expertise at a British based transnational firm, found that mentors gave advice and helped instill in their employees a larger sense of the company's mission and helped them identify their role with that community. Mezias and Scandura (2005) assert that for expatriates to understand implicit socially and culturally embedded behavior is difficult, and that a peer mentor with host-country experience may help expatriates navigate their new environment. .

Working across international borders and with different cultures, may make expatriate assignments even more complex for individuals whose race differs from the majority of residents of their international location. In this instance, mentors may play a vital role in assisting African American expatriates negotiate the cultural landscape. Despite evolving research examining the role of mentors during international assignments (Black, 1992; Black and Gregensen, 1991; Black, Gregersen, Mendenhall and Oddou, 1991; Crocitto, Sullivan and Caarraher, 2005; Feldman, Folks and Turnley, 1999; Feldman and Thomas, 1992; Harvey and Wiese, 1998; Mezias and Scandura, 2005; Scandura and Von Glinow, 1997; Shumsky, 1993) only limited research (Davison and Punnett, 1995) examines the role of race in the expatriate relationship. We assert that the consideration of race in expatriate mentoring relationships has been neglected, despite findings suggesting that mentoring is an important factor for the career development of racial minority executives (Catalyst, 1999 and 2001). MNCs' growing interest in global diversity creates an opportunity to consider the advantages of better understanding what aspects of mentoring can create successful and effective expatriate assignments for African American minority expatriates.

\section{RELATIONAL DEMOGRAPHY}

Organizational researchers often adopt a relational demography approach to uncover the impact of employees' demographic characteristics on job behaviors and attitudes. Byrne's (1971) similarity-attraction paradigm, which serves as the underpinning of the relational demography approach, implies that individuals tend to be attracted to those who are more similar to them. Relational demography research contends that individuals, who are similar in regards to characteristics such as age, gender, race, education and job tenure, etc., behave more favorably toward each other than individuals who are demographically dissimilar. Findings suggest that demographic similarity is positively related to critical job outcomes such as job satisfaction, communication and superior-subordinate mentoring relationships (Ensher \& Murphy, 1997; Green, Anderson, \& Shivers, 1996; Tsui \& O'Reilly, 1989; Turban \& Jones, 1988; Vecchio \& Bullis, 2001; Wesolowski \& Mossholder, 1997; Wharton, Rotolo, \& Bird, 2000; Zenger \& Lawrence, 1989).

Studies examining the role of demographic race found that individuals preferred to work with others of the same race (Hinds Carley, Krackhardt and Wholey, 2000); formed mentoring relationships among individuals who were similar in race (Turban, Dougherty, and Lee, 2006); and that Black subjects were attracted by corporate recruitment diversity advertisements (Avery, 2003). We agree with Riordan, Schaffer and Stewart (2005:39) who assert that, "demographic characteristics are for the most part immediate and highly salient and thus can strongly affect members' attitudes and perceptions about the group". Saliency may become a significant issue for African American expatriates depending upon their international location. Expatriate deployment parallels the changing 
global business landscape. A recent survey by the United Nations Conference on Trade \& Development (UNCTAD) suggests that the top three investment hot spots for the next several years are China, India and the United States (UNCTAD, 2008). A review of the 2007 US foreign direct investment (FDI) locations abroad suggests that outside of Europe, the largest increases in FDI were in the Asia /Pacific regions specifically China and India (Ibarra \& Koncz, 2008). Correspondingly, for American MNCs, the critical locations for expatriate assignments are China and India. Given the racial homogeneity among the residents of these locations, we can speculate that small numbers of African Americans reside in China and India and, consequently, they may experience the effects of increased saliency discussed in Kanter's (1977) influential research on tokens. This interesting dynamic warrants consideration of the impact African American expatriates race on their mentoring relationships. We now, take a more in-depth view, by utilizing a relational demography approach when examining relational race in mentoring relationships.

\section{ACCESS TO MENTORS}

Review of the similarity-attraction paradigm related to the impact of demographic factors, such as gender and race, on mentoring relationships highlights interesting results. One body of research investigating access to mentors by women and racial minorities suggests that they are as equally likely to have mentors as their male and White peers (Ragins, 1999; Wanberg, Welsh, \& Hezlett, 2003). Whereas, other findings underscore the difficulties that women and minorities have gaining access to mentors (Bell and Nkomo, 2001; Dreher and Cox; 1996; Giscombe and Mattis, 2002; McGuire, 1999 Ragins and Cotton, 1991; Viator, 2001).

Recent research examining the challenges that people of color face accessing mentors suggest that the access issue may “...be a function of the specific attributes of mentors whom protégés of color receive (or select) along with the organizational context that either supports or acts as a barrier to the formation of interracial development relationships." (Blake-Beard, Murrell and Thomas, 2007:228). The American workplace is fraught with increases in layoffs and limited advancement opportunities which forecasts increased challenges in obtaining a mentor for women and people of color due to an increase demand and limited supply of mentors (Kilian, Hukai and McCarty, 2005). For African American expatriates, access to mentors may be compounded by this changing workplace, their racial saliency, and an organizational context that confirms a gap between American MNCs' domestic and international diversity operations (Egan and Bendick, 2003). We propose these barriers may influence African American expatriates' ability to obtain a mentor.

P1: African American expatriates are more likely to experience barriers to obtaining a mentor depending upon their international location.

\section{TYPES OF MENTORING}

Researchers investigating the type of mentoring support protégés receive found mixed results with respect to race. Cox and Nkomo's (1991) investigation of mentoring among graduate business students reported less mentoring among Black respondents than White respondents. McGuire (1999) found that White protégés received more instrumental help than protégés of color and that protégé' of color received more psychosocial help than white protégés. Additional findings indicated that African American accountants reported levels of career support and psychosocial support that tended to be less than that reported by their Caucasian counterparts (Viator, 1991). Conversely, Blake-Beard (1999), in her study examining the effect of protégé race on the influence of mentoring on the career outcomes of Black and White female MBA graduates, found no race differences in the amount of mentoring received by respondents. Blake-Beard (1999) advises caution, however, when interpreting the results because peer mentoring that women draw upon for psychosocial support was not included in the study. These contradictory findings highlight the need for additional research to clarify the relationship between race and mentoring functions.

P2: African American expatriates are more likely to receive more psychosocial support than White expatriates from their mentors.

P3: African American expatriates are more likely to receive less career support than White expatriates from their mentors. 


\section{SAME-RACE AND CROSS RACE MENTORING}

Previous research confirms that women and minorities are more likely to be in cross-race mentoring relationships than their counterparts (Ragins, 1989; Ragins and McFarlin, 1990; Thomas, 1990; Thomas \& Alderfer, 1989). Although there is a scarcity of research examining mentor/protégé racial diversity in international settings, the European and Asian/Pacific Rim countries are frequent transfer destinations for American expatriates (Atlas, 2008); we speculate that racially diverse expatriates are more often in cross-race rather than same-race mentoring relationships.

Findings suggests that same-race relationships provided significantly more psychosocial support than crossrace relationships (Thomas, 1990) and that protégés with same-race mentors reported more instrumental support than those with different race mentors (Ensher and Murphy, 1997). Research examining same race versus cross race developmental relationships in a British setting indicated that Black Britons who worked for a Black supervisor in an all or predominantly Black work group had a more positive work experience than those with White supervisors (Kirby and Jackson, 1999). We consider this will also be true for African American expatriates.

P4: American expatriates with same race mentors are more likely to receive more psychosocial support than those with cross race mentors.

\section{FEMALE EXPATRIATES}

Research on the female expatriate experience examines the desire to go abroad (Adler, 1984a; Stroh, Varma and Valy-Durbin, 2000), acceptance by host nationals (Napier and Taylor, 1995; Caliguri and Cascio, 1998), adjustment (Black et. al., 1991; Harris, 2004), and assignment success (Caligiuri and Tung, 1998). Findings, which focused on relationships, suggest support from the company and family (Caligiuri, Joshi and Lazarova, 1999) social interaction (Caliguri and Lazarova, 2000)and host national social support (Taylor and Napier, 1996) had a positive impact on female expatriate adjustment. Despite the rise in female expatriates, few studies to our knowledge examine the experiences of the female expatriates of color (Tzeng, 2006). The rise in female expatriates coupled with the increasing diversity of the American workforce necessitates investigation of this emergent group of expatriates.

Previous research identifies the scarcity of female mentors (Noe, 1988; Ragins, 1989) due to the limited pool of upper level female managers; subsequently few studies examine the female mentor-male protégé mentoring dyad (Burke, 1984; Ragins and McFarlin, 1990). Similar to dyads where the mentor and protégé dyads are both domestically based, we expected a shortage of female mentors for expatriate mentoring dyads; therefore, we focus our discussion only on women of color in cross gender mentoring relationships.

Studies examining the impact of relational gender on employee mentoring interactions suggest that crosssex mentoring relationships were more likely to have been initiated by the mentor, whereas same-sex relationships were more likely to have been mutually initiated (Gaskill, 1991). Cross gender protégés were less likely than samegender protégés to report engaging in after-work social activities with their mentors (Ragins and McFarlin, 1999). Research results also indicate that both male and female mentors were less comfortable and confident in crossgender mentoring pairs than same gender pairs (Elliott, Leck,, Orser,, Mossop, 2006). Additional findings indicated that female protégés with female mentors indicated more role modeling than those with male mentors (Ragins and McFarlin, 1999; Burke, Burgess and Fallon, 2006). In a study of interns on international assignments, Feldman et. al, (1999) found that interns in cross gender mentoring relationships were less likely to receive task-related, socialrelated and career-related support from their mentor than those in same-sex relationships. These results call attention to the gender differences experienced by protégés. Moreover the literature underscores the negative perceptions associated with cross gender mentoring ranging from increased visibility due to real or imaged sexual fears and tension (Kram, 1983; Olain, Carroll, Giannantonio, 1993) to female protégés' lack of managerial skill and unsuitability for challenging assignments (Noe, 1988). A study of mentoring among minority females found evidence implying that it was riskier for white males to mentor a minority because the token status subjects this mentoring dyad to more scrutiny than a traditional homogenous dyad (Wilson, 1994). It's possible that mentoring women expatriates of color may intensify these perceptions and subsequently decrease the positive benefits 
associated with mentoring such as organizational socialization and the employees' ability to 'learn the ropes', which often occurs through role modeling. Effective role modeling becomes a necessity for expatriates attempting to negotiate the cultural landscape while meeting performance standards. Developing sensitivity to country specific business practices and related cultural nuances is vital for expatriate managers. Role modeling offered through mentoring relationships may assist expatriates in gaining an appreciation of different cultural practices and the opportunity to learn how to adapt their behavior.

P5: African American expatriates with female mentors are more likely to agree that their mentor served as a positive role model than those with male mentors.

\section{MULTIPLE MENTORS}

Discussions of mentoring in a global context focus on the at-home mentors' role in keeping the expatriate abreast of corporate changes on the home front and their assistance with repatriation (Vermond, 2001). Comparable discussions examining on-site mentors point out their role in expatriates' cultural adjustment (Black, 1992; Black and Gregersen, 1991; Black et. al., 1991). Relying on one individual, a single mentor, to share the requisite knowledge, skills and techniques with a protégé is challenging, difficult and unrealistic.

Recent conceptual work on international mentoring discusses the necessity for multiple mentors with diverse competencies who provide information and answer questions related to cultural nuances, work roles, and host country office culture (Crocitto, Sullivan, and Carraher, S., 2005; Mezias and Scandura, 2005). In essence, employees with a variety of mentors with whom they simultaneously consult for guidance on navigating the global landscape may reduce the number of obstacles they often face. While the concept of multiple mentoring awaits empirical investigation in the global context, domestic research findings indicate multiple mentors impact protégés' retention and promotion (Higgins and Thomas, 2001); work satisfaction (van Emmerik, 2004); organizational commitment, greater job satisfaction, enhanced career expectations, increased perceptions of alternative employment, and lower ambiguity about their work role (Baugh and Scandura, 1999); and decision to change careers (Higgins, 2001).

With regard to race, findings indicate that high potential racial minorities who advance the furthest share one characteristic-a strong network of mentors and corporate sponsors who nurture their professional development (Thomas, 2001). The career needs of women of color are more likely to be met if they have multiple mentors (Catalyst, 2002). Generally, the supply of mentors is limited and more specifically, racially diverse mentors are a scarce commodity. Mentors' positive impact on expatriate adjustment combined with the dynamic global marketplace accentuates the need for African American expatriates to seek out multiple mentors. As De Janasz et. al. (2003:80) emphasizes, "a diverse set of mentors will help bridge the wide range of employee expectations, values and work habits and allow executives to take advantage of the diversity which this new workforce offers". For the African American expatriates, maintaining contact with a mentor in their home location and establishing one while on assignment may aid their adjustment and repatriation.

P6: Maintaining regular contact with a mentor in their home location and on-site aids the international adjustment and career development of African American expatriates.

\section{IMPLICATIONS FOR THEORY AND PRACTICE}

The purpose of this article was to examine African American expatriates' mentoring relationships. As corporations continue to expand their partnerships across country borders, the opportunities for numerous international assignments simultaneously increase. To meet this increased demand it's likely that more African American employees will seek out and be sought out to work abroad. Our focus on racially diverse expatriates attempts to answer the call for the consideration of diversity characteristics such as race and gender in the mentorprotégé dyad occurring in international settings (Mezias and Scandura, 2005; Scandura and VonGinlow, 1997). By concentrating on relational race and gender in mentoring relationships, we bring attention to demographics that are likely to affect international adjustment and the mentoring outcomes of an emerging expatriate population. 
Investigation of African American expatriate mentoring experiences can inform the growing global diversity and mentoring literatures and potentially identify ways to foster successful and rewarding expatriate mentor interactions. Additionally, minority managers' history of meeting performance goals while negotiating the differences between their culture and the dominant culture may enlighten their expatriate experience. Subsequently these expatriates may have an advantage when encountering cultural differences, which may affect their adaptation and decrease expatriate failure rates.

Additionally, examination of the minority expatriates mentoring experiences will also enhance the literature on diversified mentoring relationships. Clarification of how relational race and gender affects relationships in a global context can increase our understanding of the mentor's role in career development. Furthermore, investigation of African American protégés' use of multiple mentors may highlight the resources needed to manage the expatriate assignment cycle (Crocitto, Sullivan and Carraher, 2005). Empirical investigation is needed to fully understand these relationships.

Practically, clarification of the racially diverse expatriates' experiences may augment expatriate training and mentoring programs. Clearly many of the issues addressed in pre-departure programs that are of concern to the majority population expatriates are similar to the issues faced by African American expatriates. We agree that discussion of language training, family matters, and cultural differences are vital to expatriate success. We suggest that cross-cultural training and mentoring programs consider issues faced by the emerging racially diverse expatriate population. Working and living outside of one's home country can be a rewarding yet challenging experience; however, the inclusion of cultural and racial differences adds a layer of complexity. Guidance from one or multiple mentors coupled with an appreciation of the dynamics of race may ensure that the expatriate gains requisite experience for career success and that the international operations fully benefit from the minority manager's diverse perspective.

\section{AUTHOR INFORMATION}

Daria C. Crawley, Ph.D. (University of Michigan) is Assistant Professor of Management at Robert Morris University. Dr. Crawley has taught internationally in Slovakia and Germany, studied public policy legislation in the European Union while working for a Member of British Parliament and worked as a management consultant in Jamaica. Her current research examines the career experiences of ethnic minority expatriates, the impact of technology on student learning and issues centering on diversity and pedagogy.

Charlotte B. Broaden, DBA (Southern New Hampshire University) is an Associate Professor of International Business and Organizational Leadership. Dr. Broaden spent several years as a corporate expatriate in Toronto Canada where she had the responsibility of managing expatriate activities for a multinational corporation. Additionally, Dr. Broaden spent time living and working abroad as an academic in both Athens, Greece and Dubai, United Arab Emirates. She has a broad base of research interests in relation to multinational corporations, including the impact of overseas assignments, career advancement and the impact of failed expatriate assignments.

Darlene Y. Motley, Ph.D. (University of Pittsburgh) is the department head of Management and director of the Master's of Science in Human Resource Management program at Robert Morris University. Dr. Motley serves on the University Diversity Committee and heads the Business School Ethics Committee. Professor Motley's academic interests include the study of multicultural diversity, trust, and ethical behavior in students and individuals in the workplace. Her research also includes the cross-cultural and human resource impact of multiple generations in corporate and nonprofit organizations. She also works with local organizations on their diversity and human resource issues.

\section{REFERENCES}

1. Adler, N.J. (1984). Women do not want international careers: and other myths about international management. Organizational Dynamics, 13(2), 66-79.

2. Allen, T. D., Eby, L. T., Lentz, E. \& Lima, L. (2004). Career benefits associated with mentoring for protégés: A meta analysis. Journal of Applied Psychology, 89, 127-136. 
3. Atlas, (2008) “Corporate Relocation Survey 2008” retrieved September 25, 2008, from http://www.atlasworldgroup.com/survey/results.aspx?id=cCurrent

4. Avery, D. (2003). Reactions to Diversity in Recruitment Advertising-Are Differences Black and White? Journal of Applied Psychology, 88(4), 672-679

5. Baugh, S. G. \& Scandura, T. (1999). The Effect of Multiple Mentors on Protege Attitudes Toward the Work Setting. Journal of Social Behavior \& Personality, 14(4), 503-521.

6. Bell, E. L., \& Nkomo, S. M. (2001). Our separate ways: Black and White women and the struggle for professional identity. Cambridge, MA: Harvard Business School Press.

7. Black, J. S. (1992). Socializing American expatriate managers overseas. Group and Organization Management, 17, 171-192.

8. Black, J.S. \& Gregersen, H (1991). The other half of the Picture: Antecedents of Souse Cross-Cultural Adjustment. Journal of International Business Studies, 22(3), 461-477.

9. Black, J.S. \& Gregersen, H. \& Mendenhall, M.E, Oddou, G (1991). Toward a comprehensive model of international adjustment: an integration of multiple theoretical perspectives. Academy of Management Review, 16(2), 291-317.

10. Blake-Beard, S. (1999). The Costs of Living as an Outsider Within: An Analysis of the Mentoring Relationships and Career Success of Black and White women in the Corporate Sector. Journal of Career Development, 26(1), 21-36.

11. Blake-Beard, S, Murrell, A. \& Thomas, D. (2007). Unfinished Business: The Impact of Race on Understanding Mentoring Relationships in B. R. Ragins and K..Kram (Eds.), The Handbook of Mentoring at Work: Theory, Research and Practice, (pp. 223-247). New York: Sage Publications,.

12. Burke, R., Burgess, Z. \& Fallon, B. (2006). Benefits of mentoring to Australian early career women managers and professionals. Equal Opportunities International, 25(1), 71-79.

13. Byrne, D. (1971). The attraction paradigm. New York: Academic Press.

14. Caligiuri, P., Joshi, A. \& Lazarova, M. (1999). Factors influencing the adjustment of women on global assignments. International Journal of Human Resource Management, 10 (2), 163-179.

15. Caligiuri, P. \& Lazarova, M. (2002). A model for the influence of social interaction and social support on female expatriates' cross-cultural adjustment. International Journal of Human Resource Management, 13(5), 761-772

16. Caligiuri, P., Philips, J., Lazarova, M., Tarique, I., \& Burgi, P. (2001). The theory of met expectations applied to expatriate adjustment: the role of cross-cultural training. International Journal of Human Resource Management, 12(3), 357-372.

17. Caligiuri, P. \& Tung, R. (1999). Comparing the success of male and female expatriates from a US based multinational company. International Journal of Human Resource Management, 10(5), 763-82.

18. Catalyst (1999). Women of Color in Corporate Management: Opportunities and Barriers. New York, NY.

19. Catalyst (2002). Women of Color in Corporate Management: Three Years Later. New York, NY.

20. Cox, T. \& Blake, S. (1991). Managing cultural diversity: Implications for organizational competitiveness. Academy of Management Executive, 5(3), 45 - 56.

21. Crocitto, M. Sullivan, S. \& Carraher, S. (2005). Global mentoring as a means of career development and knowledge creation, Career Development International, 10(6/7), 522-587.

22. Davison, E., \& Punnett, B. J. (1995). International assignments: is there a role for gender and race in decisions?. International Journal of Human Resource Management, 6(2), 411-441.

23. de Janasz, S. C., Sullivan, S. E., \& Whiting, V. (2003). Mentor networks and career success: Lessons for turbulent times. Academy of Management Executive, 17(4), 78-91

24. Downes, M., Thomas, A. \& Singley, R. (2002) Predicting expatriate job satisfaction: the role of firm internationalization. Career Development International, 7(1), 24-36.

25. Dreher, G. F. \& Ash, R. A. (1990). A comparative study of mentoring among men and women in managerial, professional, and technical positions. Journal of Applied Psychology, 75, 539-546.

26. Dreher, G \& Cox, T. (1996). Race, gender, and opportunity: A study of compensation attainment and the establishment of mentoring relationship. Journal of Applied Psychology, 81(3), 297-309.

27. Dreher, G. \& Chargio, J. (1998). Gender, mentoring experiences and salary attainment among graduate of an historically black university. Journal of Vocational Behavior, 53, 401-416.

28. Dunavant, B. \& Heiss, B. (2005). Global Diversity. (Washington, D.C.: Diversity Best Practice). 
29. Elliott, C., Leck, J., Orser, B. \& Mossop, C. (2006). An Exploration of Gender and Trust in Mentoring Relationships. Journal of Diversity Management, 1(1), 1-11.

30. Egan, M. \& Bendick, M. (2003). Workforce Diversity Initiatives of U.S. Multinational Corporations in Europe. Thunderbird International Business Review, 45(6), 701-727.

31. Ensher, E.A. \& Murphy, S.A. (1997). Effects of race, gender, perceived similarity, and contact on mentor relationships. Journal of Vocational Behavior, 50, 460-481.

32. Fagenson, E. A. (1989). The mentor advantage: Perceived career/job experiences of proteges vs. nonproteges, Journal of Organizational Behavior, 10, 309-320.

33. Feldman, D., Folks, W. \& Turnley, W. (1999). Mentor-protege diversity and its impact on international internship experiences. Journal of Organizational Behavior, 20(5), 597-611.

34. Feldman, D.C. \& Thomas, D.C. (1992) Career management issues facing expatriates, Journal of International Business Studies, 23(2), 271-293.

35. Florkowski, G. (1996). Managing Diverstiy withing International Firms for Competitive Advantage (pp. 337-364 ) in E. E. Kossek \& S. Lobel (Eds.), Managing Diversity: Human Resource Strategies for Transforming the Workplace. City publisher

36. Gaskilll, L. (1991). Same-sex and cross-sex mentoring of female protégés: A comparative analysis. Career Development Quarterly, 40(1), 48-64.

37. Giscombe, K \& Mattis, M. (2002). Leveling the playing field for women of color in corporate management. Journal of Business Ethics, 37(1), 103-119.

38. Green, S., Anderson, S. \& Shivers, S. (1996). Demographic and organizational influences on leadermember exchange and related work attitudes. Organizational Behavior and Human Decision Processes, 66, 203-214.

39. Harvey, M. \& Weise, D. (1998). Global dual-career mentoring: A phase model approach. Human Resource Planning, 21(2), 33-48.

40. Harvey, M., Buckley, M., Novicevic, M. \& Wiese, D. (1999a). Mentoring dual-career expatriates: a sensemaking and sense-giving social support process. International Journal of Human Resource Management, $19(5), 808-827$.

41. Higgins, M. (2001). Changing careers: the effect of social context”, Journal of Organizational Behavior, 22(6), 595-618.

42. Humphries, M. \& Grice, S. (1995). Equal Employment Opportunity and the Management of Diversity: A global Discourse of Assimilation?. Journal of Organizational Change Management, 8(5), 17-32.

43. Ibarra, M. \& Koncz, J. (2008). Direct Investment Position for 2007: Country and Industry Detail. Retrieved July 30, 2008, www.bea.gov/scb/pdf/07\%20July/0708.dip.pdf

44. Illes, P (1995). "Learning to Work with Difference. Personnel Review, 24(6), 44-60.

45. Harvey. M. \& Wiese, D. (1998). The dual-career couple: female expatriates and male trailing spouses. Thunderbird International Business Review. 40(4), 359-88.

46. Hinds, P. J., Carley, K. M., Krackhardt, D. \& Wholey, D. (2000). Choosing work group members: Balancing similarity, competence and familiarity. Organizational Behavior and Human Decision Processes, 81, $226-251$.

47. Kamoche, K. (2000). Developing Managers: The Functional, the Symbolic, the Sacred and the Profane. Organization Studies, 21(4), 747-774.

48. Kanter, R. M. (1977).Some effects of proportions on group life: Skewed ratios and responses to Token Women. American Journal of Sociology, 82, 965-990.

49. Kilian, C. M., Hukai, D. and McCarty, E. E. (2005). Building diversity in the pipeline to corporate leadership. Journal of Management Development, 24 (1/2), 155-168.

50. Koberg, C. S., Boss, R.W., Chappell, D. \& Ringer, R. C. (1994). Correlates and consequences of protégé mentoring in a large hospital. Group and Organization Management, 19, 219-239.

51. Konrad, A. (2003). Defining the Domain of Workplace Diversity Scholarship. Group \& Organization Management, 28(1), 4-17.

52. Kram, K. (1985). Mentoring at work. Glenview, IL: Scott, Foresman.

53. Lankau, M \& Scandura, T. (2002). An Investigation of Personal Learning in Mentoring Relationships: Content, Antecedents and Consequences. Academy of Management Journal, 45(4), 779-790. 
54. McGuire, G. M. (1999). 'Do race and gender affect employees' access to and help from mentors? Insights from the study of a large corporation. In A. Murrell, F. Crosby \&R. Ely (Eds.), Mentoroing dilemmas: Development relationships within Multicultural Organizations, (pp.105-120). New Jersey: Lawrence Erlbaum.

55. Mezias, J.M. \& Scandura, T.A. (2005). A needs-driven approach to expatriate adjustment and career development: a multiple mentoring perspective, Journal of International Business Studies, 36(5), 519-538.

56. Mullen, E. J. (1994). Framing the mentoring relationship as an information exchange. Human Resource Management Review. 4, 257-281.

57. Napier, N. \& Taylor, S. (1995). Western women working in Japan: Breaking Corporate Barriers. Greenwich, CT: Quorum Press.

58. Noe, R. (1988). Women and Mentoring: A Review and Research Agenda, Academy of Management Review, 13(10), 65-78.

59. Olian, J.D., Carroll, S. J. \& Giannantonio, C. M. (1993). Mentor reactions to protégés: An experiment with managers. Journal of Vocational Behavior, 43, 266-278.

60. ORC Worldwide (2002). "Diversity Policies and Practices for Expatriates in North American-based Companies", Workforce Opportunity Network Memo -02-020, April 18, 2002.

61. Ostroff, C. and Kozlowski, S. (1993). The role of mentoring in the information gathering of newcomers during early organizational socialization. Journal of Vocational Behavior, 42, 170-183.

62. Ragins B. R. (1989). Barriers to mentoring: The female manager's dilemma. Human Relations, 42, 1-22.

63. Ragins, B. R. (1999). Gender and mentoring relationship: A review and research agenda for the next decade. In G. N. Powell (Ed.), Handbook of gender and work (pp. 347-370). Thousand Oaks, CA: Sage.

64. Ragins, B.R. \& Cotton J.L. (1999). "Mentor functions and outcomes a comparison of men and women in formal and informal mentoring relationship", Journal of Applied Psychology, 84(4), 529-550.

65. Ragins, B. R. \& Kram, K. E. (2007). The Roots and Meaning of Mentoring. in Belle Rose Ragins \& Kathy Kram (Eds.), The Handbook of Mentoring at Work: Theory, Research and Practice. (pp. 3-15). Los Angeles: Sage Publications

66. Ragins, B. R. \& McFarlin, D. B. (1990). Perceptions of Mentor Roles in Cross-Gender Mentoring Relationships, Journal of Vocational Behavior, 37, 321-339.

67. Riordan, C., Schaffer, B, \& Stewart, M. (2005). Relational demography within groups: Through the lens of discrimination. In R. Dipboye \& A. Collela (Eds.), Frontiers in discrimination. Mahwah, NJ: Lawrence Erlbaum Associates.

68. Scandura, T. A. (1992). Mentorship and Mobility: An empirical investigation, Journal of Organizational Behavior, 13, 169-174.

69. Scandura, T.A. \& Von Glinow, M.A. (1997). Development of the international manager: the role of mentoring', Business and the Contemporary World, 9, 95-115.

70. Shumsky, N.J. (1993). Keeping track of global managers', The Human Resources Professional, 5(4), 6-10.

71. Sippola, A. \& Smale, A. (2007). The global integration of diversity management: a longitudinal case study. International Journal of Human Resource Management, 18(11), 1895-1916.

72. Stroh, L. Varma, A. \& Valy-Durbin, S (2000). Why are women left at home: are they unwilling to go on international assignments. Journal of World Business, 35(3), 241-255.

73. Swaak, R (1997). Repatriation: A weak link in global HR. HR Focus, 74(4), 29-30.

74. Thomas, D. A. (1990). The impact of race on managers' experiences of development relationships (mentoring and sponsorship): An intra-organizational study, Journal of Organizational Behavior, 11(6), 479-492.

75. Thomas, D. A. (2001). The truth about mentoring minorities: Race matters. Harvard Business Review, 79(4), 99-107.

76. Thomas, D. A. \& Alderfer, C. (1989). The influence of race on career dynamics: Theory and research on minority career experiences. In M.B. Arthur, D. T. Hall \& B. S. Lawrence (Eds.), Handbook of career theory, (pp.133-158). Cambridge, UK:Cambridge University Press.

77. Thomas, D. \& Higgins, M. (2001). Mentoring and the Boundaryless Career: Lessons from the Minority Experience. In M. Arthur \& D. Rousseau (Eds.) The Boundaryless Career: A New Employment Principle for a New Organizational Era, (pp. 268-282). New York: Oxford University Press.

78. Toosi, M. (2005). Employment outlook: 2004-2014 Labor force projections to 2014: retiring boomers. Monthly Labor Review, November, 25-44. 
79. Turban, D \& Jones, A. (1988). Supervisor-Subordinate Similarity: Types, Effects, and Mechanisms. Journal of Applied Psychology, 73(2), 228-234.

80. Turban, D. Dougherty, T \& Lee, F. (2002). Gender, Race and Perceived Similarity Effects in Development Relationships: The Moderating Role of Relationship Duration. Journal of Vocational Behavior, 61, 240262.

81. Tzeng, R. (2006). Gender issues and family concerns for women with international careers: Female expatriates in Western multinational corporations in Taiwan. Women in Management Review, 21(5), 376380 .

82. U.S. Census (2000). "Racial and Ethnic Classifications Used in Census 2000 and Beyond" Retrieved August 18, 2008 from http://www.census.gov/population/www/socdemo/race/racefactcb.html

83. United Nations Conference on Trade and Development (UNCTAD) New Take-Off Predicted for FDI: Findings of a joint UNCTAD-Corporate Location survey of International location experts. Retrieved July 30, 2008 from www.unctad.org/Templates/webflyer.asp?docid=4720\&intItemID=2807\&lang=1.

84. van Emmerik, I.J.H. (2004). The more you can get, the better: mentoring constellations and instrinsic career success. Career Development International, 9(6), 578-594.

85. Viator, R. E. (2001). An examination of African Americans access to public accounting mentors: perceived barriers and intentions to leave. Accounting, Organizations \& Society, 26(6), 541-561.

86. Vecchio, R. \& Bullis, R.(2001). Moderators of the Influence of Supervisor-Subordinate Similarity of Subordinate Outcomes. Journal of Applied Psychology, 86(5), 884-896.

87. Vermond, K. (2001). Expatriates Come Home. CMA Management, 75(7), 30-34;

88. Wanberg, C. R., Welsh, E. T, \& Hezlett, S. A. (2003). Mentoring research: A review and dynamic process model. In J. J. Martocchio \& G. R. Ferris (Eds.), Research in personnel and human resources management. Vol. 22 (pp. 39-124). Oxford, UK: Elsevier Science Ltd.

89. Wentling, R. M. \& Palma-Rivas, N. (2000). Current Status of Diversity Initiatives in Selected Multinational Corporations. Human Resource Development Quarterly, 11(1), 35-60.

90. Wesolowski, M \& Mossholder, K (1997). Relational demography in supervisor-subordinate dyads: Impact on subordinate job satisfaction, burnout, and perceived procedural justice. Journal of Organizational Behavior, 18(4), 351-362.

91. Wharton, A, Rotolo, T. \& Bird, S. (2000). "Social Context at Work: A Multilevel Analysis of Job Satisfaction." Sociological Forum, 15, 65-89.

92. Whitely, W. \& Coetsier, P. (1993). The relationship of career mentoring to early career outcomes, Organization Studies, 14(3), 419-442.

93. Whitely, W., Dougherty, T. W. \& Dreher, G. F. (1991). Relationship of career mentoring and socioeconomic origin to managers' and professionals' early career progress', Academy of Management Journal, 34, 331-351.

94. Wilson, S. A. (1994). Mentoring minority female professionals: Strategies for successful relationships. Proceedings of Diversity in Mentoring. Atlanta, GA 357-368.

95. Zenger, T. \& Lawrence, B. (1989). Organizational demography: The different effects of age and tenure distributions on technical communication. Academy of Management Journal. 32, 353-376. 
NOTES 